\title{
Effect of Organizational Ethics On Service Delivery of Employees in The Public Sector: A Nigerian Perspective
}

\author{
Umar Abbas Ibrahim, $\mathrm{PhD}^{1^{*}}$ Maryam Ma'aruf Yakubu ${ }^{2}$ \\ 1. Department of Business Administration Nile University of Nigeria, Abuja, Nigeria. \\ 2. Department of Business Administration Nile University of Nigeria, Abuja, Nigeria.
}

\begin{abstract}
Organizational ethics is an emerging field in human resources, which focused on the study and practice of the ethical behavior of employees within an organization. The main purpose of this research work is to empirically investigate the influence of organizational ethics on the service delivery level of employees in the National Assembly in Nigeria. The dependent variables employed in this study are integrity, self-discipline and organizational values. The survey research design was adopted. The target population of this study comprises of 885 employees in the committees of the Senate and House of Representatives. Multi-stage sampling technique was adopted and a sample size of 171 employees was used to collect data through a closed-ended questionnaire designed on a Five-Point Likert scale. Multiple regression analysis was employed to analyze data. The study found that there is a significant and positive relationship between organizational ethics dimensions of integrity, self-discipline organizational values on service delivery of employees of the Nigerian National Assembly on the other hand. In line with the findings, it was discovered that integrity and organizational values affect employee performance more than self-discipline. The study recommended that the management of the Nigerian National Assembly Service Commission should implement the National Assembly regulations and Code of Conduct. Nigerian National Assembly Service Commission should ensure that their organizational values are well communicated to all employees in the organization for effective service delivery practices necessary to achieve organizational goals.
\end{abstract}

Keywords: Organizational values, ethics, integrity, self-discipline, service delivery, public sector

DOI: $10.7176 / \mathrm{EJBM} / 11-36-17$

Publication date: December $31^{\text {st }} 2019$

\section{Introduction}

1.1 Background

There is a limited body of knowledge on the role of organizational ethics management, systems and mechanisms in promoting and driving service delivery, especially in public sector organizations. Many scholars view ethics of an organization refers to the organization's active attempt to define its mission and core principles, to identify values that may cause tension, to seek best solutions to these tensions, and to manage the operations that maintain its values (Letendre, 2011). According to Adebayo (2014), organizational ethics is about what is morally correct, honourable and acceptable to the larger majority of the people of an organization, society or group. It is a set of principles relating to words, especially as they apply to human conduct. It includes rules that have become a set of norms of the society, group or organizations. Essentially, organizational ethics regulate what an employee would do in a different situation in the organization. Employees exhibiting good work ethics are considered eligible for higher positions and more responsibilities. They are however, responsible and dependable assets to their organizations (Adebayo, 2014). An organization that is involved in a proper framework for good governance must practice organizational ethics and corporate good values as part of its organizational culture if it must achieve higher performance (Omisore and Adeleke, 2015). According to Fox and Meyer (1995), services within the public service sector relate to both the provision of tangible public goods and intangible services themselves. Service delivery forms the basis of all government activities. According to Integrated Management Development Program for Emerging Management (2003), service means the performance of work or duty by an official or an act of helping others, or power to control or makes use of resources, or an organization or system providing the public with something useful to meet their demands. The act of delivery is defined as producing or performing, handing over, taking goods to the intended recipient, or producing results as promised or expected. Therefore, service delivery is concerned with the provision of a product or service by the government or government body to a community that it was promised to, or which is expected by that community.

Organizational ethics influence the performance of every organization due to the fact that human resource is the most important resources in every organization (Omisore and Adeleke, 2015). According to Shafritz and Russel (2005), one of the processes of public administration is the human resource, thus for services to be rendered by a 
department there is a need for personnel to be employed and attached to specific posts within the organizational structure of the particular department. This process is accompanied by; inter alia, allocation of functions, a delegation of authority, creation of communication channels and behavioral relationships. Such personnel employed, sometimes referred to as functionaries, are charged with the task of ensuring that a department's or a municipality's goals are achieved through the efficient, effective performance of duties, the requisite for success being ethical conduct and professionalism on the part of the functionaries (Shafritz and Russel, 2005). Put differently, there is little or no hope of success in the delivery of services if the public servants are not professional and their conduct not ethical.

\subsection{Statement of the Research Problem}

According to Vyas Doorgapersad and Simmonds (2011), public sector management ought to operate within the democratic prescriptions that influence the execution of public sector activities and the implementation of measures that promote normative governance. Despite efforts by governments in different parts of the world to uphold transparency and accountability, unethical conduct in various forms has persisted in recent years. There is a widespread perception that corruption is rife in the political and economic spheres of many nations of the world today. According to Gildenhuys (1991), poor, dishonest management of public affairs and corruption (immoral acts) are among the most important manifestations of unethical conduct. Maladministration and corruption in the public sector are usually widely broadcast and exaggerated, largely because the public sector is spending taxpayers' money. For practitioners in the public sector, especially for public managers, it is important that there be guidelines according to which they must cooperate and administer and direct the public service, and place subordinates on the right track precisely to prevent corruption and eliminate maladministration.

In most countries today there are increasing expectations from ordinary citizens, business leaders and Civil Society that Governments are required to establish and deliver higher standards of ethicality and integrity in the public Service, agencies of government (Ministries and parastatals), and Government operational system itself. In part, this expectation is the result of better-focused media attention and public scrutiny, and increasing impatience by ordinary citizens and Civil Society, whose members want to see an end to the corrupt practices and systems of the past. Bearing in mind the significant progress made in recent years in developing effective public Service Ethics, Codes of Conduct, transparency measures, Ethics and Integrity systems, and Anticorruption agencies, there is now a need to concentrate on three areas of concern in particular, which are directly relevant to the problems of internalizing integrity and Ethics in democratic governments and the Civil Service (Whitton, 2001; Vyas Doorgapersad and Simmonds, 2011)

In Nigeria, despite attempts by successive governments to ensure ethical standard, value and improve attitudes for better performance of the Nigerian Public Service, several challenges still militate against its efficient service delivery. Some of these challenges include unethical attitude and non-accountability of members and key players of the Nigerian public service (Beetseh and Kohol, 2013). According to Ayand (2012), other challenges faced include fraud, extortion, embezzlement, bribery, influence peddling, bestowing of favours to friends. With the widespread acclaim of negligence to ethics in the various governmental organizations in Nigeria (Ayand, 2012; Beetseh and Kohol, 2013), this study investigated the influence of organizational ethics practice on employees' service delivery in the National Assembly in Nigeria.

\subsection{Objectives of the Study}

The main objective of this study is to examine the influence of organizational ethics on service delivery of employees in the Nigerian National Assembly. However, the specific objectives are to:

i. Determine the relationship between the integrity factor and service delivery level of employees in the Nigerian National Assembly.

ii. Investigate the effect of self-discipline factor on the service delivery level of employees in the Nigerian National Assembly.

iii. Examine the impact of organizational values on service delivery level of employees in the Nigerian National Assembly.

1.4 The research questions developed are:

i. To what extent does integrity factor influence service delivery level of employees in the Nigerian National Assembly?

ii. Is there any relationship between self-discipline factor and service delivery level of employees in the Nigerian National Assembly?

iii. How do organizational values affect service delivery level of employees in the Nigerian National Assembly? 
1.5 Statement of Hypotheses

Following the above research questions, the formulated hypotheses for testing are:

HO1: There is no significant relationship between integrity factor and service level of employees in the Nigerian National Assembly.

$\mathbf{H O}_{2}$ : There is no significant relationship between self-discipline factor and service delivery level of employees in the Nigerian National Assembly.

HO3: There is no significant relationship between organizational values and service level of employees in the Nigerian National Assembly.

\section{Literature Review}

Public and private organizations around the world maintain codes of corporate performance for managing ethical performance (Omisore and Adeleke, 2015). As Martin and Cullen (2006) stated, ethics can be described as the application of the processes and theories of moral philosophy to a real situation that is also concerned with the basic principles and concepts that guide human beings in thought and action, and which underline their values. Similarly, Messick and Bazerman (1996) also understood ethics to be the basis on which people, individually or collectively, decide that certain actions are right or wrong, and whether one ought to do something or has a right to do something. Significantly, ethics is applied to several dimensions of human and collective pursuit of vision or mission. It is this context that, Vargo and Lusch (2004) concluded ethics is valuable in an organizational setting because ethics can serve as a facilitator of relationship networks and as a skill and knowledge source for stakeholders and organizations.

\subsection{Concept of Organizational Ethics}

Akonti (2013) describes organizational ethics as an applied ethical discipline that addresses the moral choices that are influenced and guided by values, standards, principles, rules and strategies associated with organizations' activities and business situations. A standard ethical culture in an organization provides direction and guidance in various areas in order to build united, harmonious and ethical employees. Moral values that form the subject matter of ethics are about the way people ought to behave in terms of the commitment to their work and their team. As Adewale et al (2015) stated, the extent to which employee encourages integrity, sense of responsibility, quality, self-discipline and sense of teamwork determines the quality to which organizational ethics contribute to job performance level. In the operating milieu of organizations, several measures or components of organizational ethics; such as integrity, organizational values and self-discipline plays significant role in assessing the efficiency and effectiveness of employees' service delivery ability and success.

2.1.1 Integrity: The concept of integrity is one of the main components of organizational ethics. According to Zainal and Hafizah (2016), integrity is the moral quality of having consistency in uprightness, which can be measured by the conduct of components and business when observed. In this context, integrity is violated when corporate governance policies and procedures are disregarded in the quest for personal and corporate gain, or in which the interest of the perpetrators overrides those of other stakeholders and the wider community. Integrity also relates to the concept of morality while morality involves telling the truth or being honest and just in all situations (Milton 2015). This indicates that a person should stick to the principles of being truthful to oneself, as it plays a fundamental role in employee pattern of assignment, sound moral, ethical principles and organizational productivity. In this context, Tsebe (2011) summarizes public Service integrity to compose of two elements: the integrity of processes (decision-making, decision implementation and management of public funds), and the integrity of personnel - the representatives and public functionaries. The administrative capacity presupposes the correct and efficient fulfilment of duties and tasks by the representatives and public functionaries. Basically, the quality of governance is the generic term that includes all these elements discussed above: professional and stable public services, human resources selection based on meritocracy, maintenance of legality, integrity and transparency through efficient legal employees.

2.1.2 Self-discipline: Nyaribo and Dennis (2015) are of the opinion that self-discipline at the workplace is an optimistic determination and efforts, which assist in developing certain traditions for guiding an individual's feelings, conduct, behaviour, thoughts, activities and habits. Self-discipline could also be seen as an act of selfcontrol, self-reliance, self-determination and self-sufficiency, which stimulates an individual to sustain his decision and drives the individual towards achieving the set goals (Zainal \& Hafizah 2016). Therefore, in order to flourish and smile, an organization must drive the need to concentrate on stimulating self-discipline at work (Zainal \& Hafizah 2016).

2.1.3 Organizational values: For Organizational values, Nyaribo and Dennis (2015) opined it to acceptable standards, which govern the behaviour of individuals within the organization, lack of which may lead to unacceptable behaviour. This means the organizational employees are expected to act in accordance with 
organizational values even when they do not support them personally. Values are an important element of organizational ethics and other social and technical system in an organization. They are things held in high esteem by an organization, which it adheres to tenaciously.

\subsection{Employee Service Delivery and Organizational Ethics}

2.2.1 Concept of Employee Service delivery: Employee service delivery is the actual delivery of service and products to the customer or clients (Lovelock and Wright, 1999). It is therefore concerned with the where, when, and how a service or product is delivered to the customer and whether this is fair or unfair in nature. The service concept defines the "how" and the "what" of service design, and helps mediate between customer or public needs and an organization's strategic intent (Goldstein, Johnston, Duffy and Rao, 2002). In the public sector, service components are often not physical entities, but rather are a combination of processes, people skills, and materials that must be appropriately integrated to result in the 'planned' or 'designed' service. It is explained as the provision of public activities, benefits or satisfaction. Services relate both to the provision of tangible public goods and intangible services (Fox and Meyer, 1995). Service delivery forms the basis of all government activities. The act of delivery is defined as producing or performing, handing over, taking goods to the intended recipient, or producing results as promised or expected. Therefore, service delivery is concerned with the provision of a product or service by the government or government body to a community that it was promised to, or which is expected by that community.

2.2.2 Organizational Ethics and Service Delivery

In a working environment, there is an employer and the employee who keep the activities of the institution rolling in order to achieve the predetermined objectives towards efficient and effective service delivery. In the case of public organization, the rendering of services for the general welfare of the community served is the main domain for its establishment and existence. Service delivery in the public sector follows a variety of approaches in terms of value systems, legislation, legal rules. In the execution of their daily functions, public officials cannot discharge their authority at will, but their conduct or behavior is monitored, controlled, supervised and managed for maximum productivity, hence the code of ethics and/or ethical principles. Embodied in the principles are guidelines from the body politic (such as political supremacy, public accountability and tenets of democracy); guidelines from community values (they include religious doctrines and value systems, fairness and reasonableness, balanced decision making, thoroughness, probity and honesty, and efficiency and effectiveness); and prescribed guidelines (such as legal rules, fundamental rights and code of ethics or conduct, right to information held by the state and administrative justice). On the contrary, it is found that public officials act in an unacceptable and unlawful (unethical) manner. Unethical conduct in government institutions comes about as a result of certain factors that have a direct effect on efficient and effective delivery. It occurs because of public officials' greed, dishonesty and to a great extent, lack of training and development (Fox et-al, 1991; Charles 2012). These factors largely result from lack of or deficient or inadequate control and accountability in a government institution. The effect of inadequate control and accountability on public service delivery has been widely acknowledged by scholars.

\subsection{Theoretical Framework}

Several theories have been developed to cover issues related to organizational ethics. Aristotle's virtue theory emphasizes that what matters in ethical behavior is the integrity of an individual's character. Kant's deontological theory on ethics propagates that there are objective ethical standards of behavior that everyone should respect. John Stuart Mill's utilitarian theory focuses on the quality of actions as propagated by the deontological theory. The difference between the two theories is that the utilitarian theory focuses on the practical consequences of an action in order to determine whether that action was right or wrong. An action is considered good when it results in the happiness of the majority of those affected by that specific action (Rossouw, 2010). Although all of these theories are open to the investigation of organizational ethics, we found the social exchange theory more apt for wider understanding relevance to the objectives of this study. The major ideas in social exchange theory are that parties enter into and maintain exchange relationships with others with the expectation that doing so will be rewarding (Blau, 1968). More so, the theory is appropriate to examining actions that are contingent on rewards reactions from others and examines two-sided, mutually contingent and mutually rewarding processes called 'transection' and relationship called 'exchange'. The theory assumes that self-interested parties transact and exchange with self-interested others in order to accomplish outcomes that neither could achieve on his own and that these exchanges could cease as soon as they are not perceived to be mutually rewarding by both parties. Exchange of benefits or giving something to a recipient that is more valuable to the recipient than it is to the giver is the underlying basis for human behaviour. By this theory, each party has something of value that the other wants. The two parties decide what to exchange and in what quantities. 


\subsection{Empirical Review}

Several studies have been carried out on organizational ethics and employee's performance. (Omisoe and Adeleke 2015; Adeyeye et al 2015, Nyanbo and Dennis 2015, Million 2015, Adewale, Jans, Hezekiah and Akinrole 2015). These studies showed that adhering to organizational ethics and code of conduct has a significant effect on employee's performance. Similarly, Omisore and Adeleke (2015) conducted a study on Work Ethics, Values, Attitudes and performance in the Nigerian Public Service using content analysis as a method of data gathering and analysis. The study revealed that work ethics, attitudes and values are influenced by the organization through the intention of tracing, motivation and coaching. It recommended that public functionaries should act justly and fairly to all, not only paying lip service to ethical conduct but also ensuring that these are manifesting and undoubtedly seen to be done. In addition, Adeyeye et al., (2015) assessed Effects of Workplace Ethics on Employees and Organizational Productivity in Nigeria. The results show that significant relationship exists between ethical standards and organizational productivity, in Nigeria and that integrity cum discipline have a negative impact on the improved productivity level of the organization, which could be attributed to the nature of these virtues being abstract and could only be seen or observed overtime. Yusra (2017) assessed the impact of business ethics on the performance of employees of Jordanian Universities. Similar to other studies, this study reported a significant positive relationship between business ethics (respect laws and regulations, justice and impartiality, respect time and perfection, honesty and straightness, and integrity and transparency) with employee's performance. Also, Ebitu and Beredugo (2015) investigated the relevance of the code of ethics on guiding the performance of service industry in Calabar and examined also their compliance level on the established code of ethics. Results show that the effective performance of the service industry was dependent on the code of ethics and that the compliance level of the established code of ethics for the service industry was high.

\section{Methodology}

The study employed a survey research design based on quantitative strategy. This is because of the need to allow for numerical representation and manipulation of observations for the purpose of describing and explaining the phenomena that those observations reflect (Jia, Cheae, Pei and Yam, 2012). The population of the study consists of 885 employees of the National Assembly serving in different committees of the Senate and the House of Representatives as at November 2019. A sample size of 171 was selected using multi-staged sampling technique from which data were collected by the use of a five-point Likert scale structured administered questionnaire.

\subsection{Data Analysis}

The data collected were analyzed using the multiple regression analysis to examine the combined effect of organizational ethics through the proxies - organizational values on service delivery of employees of the Nigerian National Assembly. Cronbach's alpha coefficient was used to test the reliability of the survey instrument.

Model specification.

The model was specified as follows:

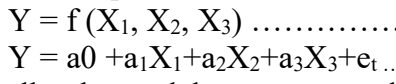

Specifically, the model was expressed in both functional and mathematical form as:

$\mathrm{SDP}=\mathrm{f}(\mathrm{INT}, \mathrm{SED}, \mathrm{OGV})$

Where:

$$
\mathrm{SDP}=\mathrm{a}_{\mathrm{o}}+\mathrm{a}_{1} \mathrm{INT}+\mathrm{a}_{2} \mathrm{SED}+\mathrm{a}_{3} \mathrm{OGV}+\mathrm{e}_{\mathrm{t}}
$$

INT $=$ Integrity

$\mathrm{SED}=$ Self-discipline

OGV = Organizational Value

$\mathrm{a}_{0}=$ Constant

$a_{1}-a_{3}=$ Coefficients of the variables

$\mathrm{e}_{\mathrm{t}}=$ error term

\subsection{Reliability of Instruments}

Cronbach's alpha coefficient was used to test the reliability of the research instruments and the result is presented in Table 1 below: 
Table 1: Cronbach's Alpha Coefficients

\begin{tabular}{ll}
\hline Variables & Coefficient \\
\hline Organizational Ethics (OE) & 0.83 \\
Integrity (IN) & 0.88 \\
Self-discipline (SD) & 0.79 \\
Organizational Values (OV) & 0.88 \\
Overall scale & $\mathbf{0 . 8 5}$ \\
\hline
\end{tabular}

Source: Researchers Computation 2019

The instruments employed for analysis is therefore considered reliable for the study since all the coefficient for variable employed in this study are above 0.7 . The model summary obtained from the regression analysis performed in this study is presented in Table 2

Table 2: Model Summary

\begin{tabular}{|l|l|l|l|l|l|l|}
\hline Model & $\mathrm{R}$ & R Square & $\begin{array}{l}\text { Adjusted } \\
\text { Square }\end{array}$ & $\begin{array}{l}\text { Std. An error of } \\
\text { the Estimate }\end{array}$ & $\begin{array}{l}\text { Sig. F Change } \\
\text { Watson }\end{array}$ \\
\hline 1 & $.541^{\mathrm{a}}$ & .532 & .281 & 1.99496 & 0.000 & 2.153 \\
\hline
\end{tabular}

a. Predictors: (Constant), Integrity, Self-discipline and organizational values

b. Dependent Variable: Service delivery

As presented in Table 2, the coefficient for the study as revealed by the model summary table is $\mathrm{R}^{2}=0.532$. This indicates that $53.2 \%$ of the variability in service delivery (dependent variable) has been significantly explained by the independent variables under study. The result obtained implies that integrity, self-discipline and organizational values are good predictors of service delivery. It can, therefore, be said that this represents a moderate contribution made by the independent variables in explaining the variability in the dependent variable. In other words, the Model Summary shows that the Independent variables succeeded in explaining 53.2 per cent of the variance in the dependent variable.

The results of the multiple regressions analysis performed to test the nature and significance of the relationship between organizational ethics and service delivery of employees of the Nigerian National Assembly is presented in Table 3.

Table 3: Result of Multiple Regression Analysis

\begin{tabular}{|l|l|l|l|l|l|}
\hline \multirow{2}{*}{ Model } & \multicolumn{2}{|l|}{$\begin{array}{l}\text { Unstandardized } \\
\text { Coefficient }\end{array}$} & $\begin{array}{l}\text { Unstandardized } \\
\text { Coefficient }\end{array}$ & $\mathrm{t}$ & Significance \\
\cline { 2 - 6 } & $\mathrm{B}$ & Standard error & Beta & & \\
\hline Constant & 3.482 & .290 & & 12.016 & .000 \\
INT & .733 & .046 & .823 & 15.934 & .004 \\
S.D & .330 & .022 & .024 & 15.11 & .203 \\
OV & .232 & .016 & .845 & 14.5 & .002 \\
\hline
\end{tabular}

Source:_Researcher's Computation 2019

Table 3 shows the result of the multiple regression analysis conducted to test the nature, degree and the significant relationship between the variables of organizational ethics and the service delivery of the employees of the Nigerian National Assembly. The statistical decision rule of $\mathrm{p}$-value states that the Null hypothesis should be accepted if P-value is greater than the alpha value (i.e. the level of the significance which is 0.05) otherwise it should be rejected while the Alternative hypothesis is adopted. This indicates that that integrity has a positive and significant effect on employee performance. The effect is positive and significant as the p-value of 0.004 is less than the alpha value (0.05). Therefore, there is no sufficient reason to accept the null hypothesis. The study, therefore, concludes that integrity has a statistically positive and significant effect on service delivery. This suggests that an increase in integrity will lead to a significant increase in service delivery. Therefore, for the Nigerian National assembly to improve service delivery, there is a need to focus on their workers' integrity.

The Table 3 also shows that self-discipline has a positive and insignificant effect on employee performance. The effect is positive and insignificant as the p-value of 0.202 is greater than the alpha value (0.05). Therefore, there is no sufficient reason to reject the null hypothesis. The study, therefore, concludes that self-discipline has a statistically positive and insignificant effect on service delivery. This implies that an increase in self-discipline 
will lead to an insignificant increase in service delivery. This indicates that for the Nigerian National Assembly to enhance service delivery there is a need to focus more on their staff integrity and values as self-discipline was found to have no significant effect on service delivery. For organizational values (OV), it shows a positive and significant effect on employee performance. The effect is positive and significant as the p-value of 0.002 is less than the alpha value (0.05). Therefore, there is no sufficient reason to accept the null hypothesis. The study, therefore, concludes that organizational values have a statistically significant effect on service delivery in the Nigerian National Assembly. This further indicates that an increase in organizational values will lead to a significant increase in service delivery in the Nigerian National Assembly. Therefore, for the Nigerian National Assembly to increase service delivery, they need to focus on their values.

\section{Discussion of Findings}

The nature of the relationship as revealed by the sign of the coefficients of the variables showed there exists a positive relationship between the organizational ethics variables and the service delivery level of the employees of the Nigerian National Assembly. The positive signs of the coefficients of the three variables of organizational ethics confirmed this position. This means that an increase in the organizational ethics variable of integrity, selfdiscipline and organizational value has the tendency to increase the service delivery level of the employees of the Nigerian National Assembly. This position confirmed the work of Adewale, James, Hezekiah and Akinoe (2015). Similarly, the significant relationship between the variables of organizational ethics and the service delivery of the employees of Nigeria National Assembly was tested with p-value and the result showed that there exists a significant relationship between the integrity and organizations value and no significant relationship between self-discipline and service delivery level. This is because the p-values of integrity factor and organizational value at 0.004 and 0.002 are less than 0.05 and p-value of self-discipline at 0.203 is greater than 0.05 .

This is drawn from the decision rule of P-value that states: If the calculated value of $\mathrm{P}$ is greater than the tabular value, reject null hypothesis, otherwise it should be rejected while the alternative hypotheses are adopted. By this, there is no significant reason to accept the null hypotheses. The study, therefore, concludes that integrity has a statistically positive and significant effect on employee performance. This indicates that an increase in integrity will bring about a significant increase in employee performance. Therefore, for the Nigerian National Assembly to increase employee performance, there is a need to focus on their worker's integrity. This is in line with the work of Milton (2015) and Zainal and Hafizah (2016). Following the rule of P-value, there is no significant reason to reject the null hypothesis that is the null hypothesis is accepted. The study, therefore, concludes that self-discipline has a statistically positive but insignificant effect on employee performance. This implies that an increase in self-discipline will lead to an insignificant increase in employee's performance. This indicates that for the Nigerian National Assembly to increase employee performance, there is a need to focus more on their staff integrity and values as self-discipline was found to have no significant effect on employee performance. This confirmed the study of (Adewale, James Hezekiah \& Akinoe 2015).

\section{Conclusion and Recommendations}

5.1 Conclusion

This article paid attention to legislative and organizational ethical mechanisms of integrity, organizational values, and self-discipline in relation to service delivery of employees. The focuses are in the legislative arm of public sector governance in Nigeria. The study paid attention to the employees serving in the 171 committees of the House of Representatives and the Senate within the National Assembly based on their roles to service delivery that could achieve the set goals of the organization needs. The emphasis first fell on the social exchange theory framework for improved service delivery. Within the application of causal relationship of the variables through the use of regression analysis, it indicate that a strong support base for ethical conduct was put in place and employees play within the orbit of ethical values and obligations. In line with the findings, the study concluded that organizational ethics in terms of integrity and organizational values affect employees' performance more than self-discipline. Therefore, the Nigerian National Assembly needs to ensure that their organizational values are well committed to all employees in the organization. Value makes employees feel that they are part of the organization and also they need to perform towards the attainment of the organizational goal. The onus is on the employees to avail themselves to the Nigerian National Assembly Commission rules to enable them enjoy the full benefits of the rights and privilege provided.

5.2 Recommendations

Based on the findings of this study, the following recommendations are made:

- The Nigerian National Assembly Service Commission should fully implement the National Assembly regulations and Code of Conduct. Also, the Nigerian National Assembly Service Commission should 
ensure that their organizational values are well communicated to all employees in the organization for effective service delivery practices necessary to achieve organizational goals.

- Channels should be put in place by the management of the National assembly to ensure that breach of organizational ethics is reported to the appropriate authorities.

- The National Assembly should additionally ensure firm and consistent application of appropriate sanctions when people of staff violate the code of conduct.

\section{Reference}

Adebayo, A.O. (2014) Ethical issues in public service, International Journal of Social Science and Humanity, 4(5), 345-370.

Adewale, G.O. James, A. A., Hezekiah, I. and Akinrole, G. (2015), Work ethics and employees job performance. Journal of Leadership, Accountability and Ethics. 12(1): 477-488

Adeyeye, J.O., Adeniji, A.A., Osinbanjo, A.O. and Oludayo, O.A (2015). Effect of workplace ethics on employees and organizational productivity in Nigeria. International Conference on African Development Issues (CU-ICADI) 2015: Social and Economic Models for Development Track

Akonti, E. O. (2013). Concept of Work and Ethics. C.M.D Training Manual

Ayand, D.O. (2012). Corruption Definition, theories and concepts. Arabian Journal of Business and Management Review, 2(4) 464-487

Beetseh, K. and Kohol, B. (2013). Challenges of ethics and accountability in Nigeria civil service, the implication for counselling. SR Journal of Humanities and Social Science, 9(2), 5566-5580

Blau, P.M. (1964). Exchange and Power in Social Life. John Wiley, New York.

Charles, S. U. (2012), Improving Organizational Productivity Through Ethics, Integrity and Professionalism'. A paper presented at a 2-day Seminar Workshop organized for Staff of Area Council Commission, Abuja by the Institute of Corporate Administration.

Ebitu, E.T. and Baradugo, S.B. (2015). Business ethics and the performance of service firms In Calabar, Cross River State, Nigeria. European Journal of Hospitality and Tourism Research 3(2), 28-38

Fox, W. and Meyer, J. (1995). Public Administration Dictionary. Pretoria: Juta.

Fox, W., Schwella, E. and Wilsink, H. (1991), Public Management. Kenwyn. Juta and Co. Ltd

Gildenhuys, J.S.H. (1991) Ethics and the public sector, Cape Town: Juta and Company.

Goldstein, S. M; Johnston, R; Duffy, J. and Rao, J. (2002). The service concept: the missing link in service design research? Journal of Operations Management, 20, 121-134.

Jia, E.A., Cheae, L.S., Pei, T.P. and Yam, Y.C. (2012). A Study of Customer Satisfaction Towards Service Quality in Airasia Malaysia (Unpublished B.Sc. Project). Universiti Tunku Abdulrahman, Malaysia.

Letendre, M.C. (2011). Organizational Ethics. Marymount International, Rome, Italy Bioethics International, New York the USA

Lovelock, C.H. and Wright, L. (1999). Principles of Service Management and Marketing. Prentice-Hall, Englewood Cliffs, New Jersey.

Martin, K. D., and Cullen, J. B. (2006). Continuities and extension of ethical climate theory: A meta-analytic review. Journal of Business Ethic, 69(2), 175-194.

Messick, D. M., and Bazerman, M. H. (1996). Ethical leadership and the psychology of decision-making, Sloan Management Review, 37(2), 9-22.

Milton, C.L. (2015) Ethics and academic integrity, Nursing Science Quarterly, 28(1), 18-20.

Nyaribo, C.L. and Dennis, J. (2015). Effect of organizational values on employee's performance a case study of urban roads authority, International Journal of Science and Research (IJSR), 6(6), 95-107.

Omisore, B.O. and Adeleke, A.O. (2015). Work Ethics, Values, Attitudes and Performance in the Nigerian Public Service: Issues, Challenges and the Way Forward, Journal of Public Administration and Governance, 5(1): 157-172

Rossouw D (2010). Key concepts in business and professional ethics, In: Prozesky, M. (ed.) Ethics for accountants and auditors. 2 nd ed. Cape Town: Oxford University Press, pp. 16-26.

Shafritz, J.M. and Russel, E.W. 2005. Introduction to Public Administration (4th ed.). New York: Pearson.

Tsebe, M. J. (2011) The Role of Ethical Principles in Promoting Efficient Service Delivery at the Department of Education in Capricorn District of Limpopo Province, A Research Report Submitted to Faculty of Administration, Graduate School of Leadership, University of Limpopo.

Vyas-Doorgapersad, S. and Simmonds, K. (2011). The Significance of Philosophical Tools for Good Governance with Reference to South Africa. Administration Publica, 19 (3), 56-72.

Whitton, H. (2001). Implementing Effective Ethics Standards in Government and the Civil Service. Transparency International.

Yusra, T.MA. (2017). Impact of Business Ethics On Employee's Performance: An Empirical Study of Jordanian Public Universities. Arabian Journal of Business and Management Review, 4(2): 44-51

Zainal, A.Z. and Hafizah, O.Z. (2016) Ethics and integrity in building employee's perception. Management Studies, 4(3),131-137. 